\title{
Post-Colonialism Perspective: Why Turkey's Efforts to Join EU always 'Go Down in Flames'?
}

Muhammad Fawwaz Syafiq Rizqullah

Universitas Muhammadiyah Yogyakarta

Email: syafiqrizqullah@gmail.com

Mahbi Maulaya

Universitas Muhammadiyah Yogyakarta

Email:mahbimaulaya99@gmail.com

\begin{abstract}
European Union (EU) is an economically advanced, politically reliable, socially progressive, and regionally integrated community, making the so-called 'the role model of world's regionalism' seem adorable in Turkey's lens. Having the opportunity to wave its flag in Brussels has been Turkey's foreign policy since 1987. Turkey's modus operandi to make the EU opening its door are enormous in scale. Yet, it does not mean that Turkey would quickly receive a lukewarm response from the EU. This paper lays down some theoretical arguments based on post-colonialism to discover why the EU has given a persistent rejection and derogation towards Turkey. As this paper stands in a post-colonialism stance, the Euro-centrism sense, which is embedded in the EU's way of thought, serves as the reason why intentional rejection is intensively addressed towards Turkey. This paper contains several features. After delivering a short introduction, there will be a modest explanation in picturing the used-theoretical framework. The discussion section stands upon three main questions; why does the EU treat Turkey differently from Greece? Is Turkey capable of fulfilling Copenhagen criteria? Does the EU tend to act in a discriminative manner to Turkey?
\end{abstract}

Keywords: European Union (EU), Turkey, Post-Colonialism, Euro-Centrism

\section{Abstrak}

Uni Eropa (UE) sudah jelas merupakan sebuah komunitas yang maju secara ekonomi, stabil secara politik, progresif secara sosial, dan terintegrasi secara 
regional. Oleh karena itu, organisasi yang dijuluki 'panutan regionalisme dunia' ini terlihat menawan di mata Turki. Mendapatkan kesempatan untuk mengibarkan benderanya di Brussel telah menjadi kebijakan luar negeri Turki semenjak tahun 1987. Sudah beragam upaya yang Turki lakukan untuk membuat UE bersedia menerimanya sebagai anggota penuh. Namun, Turki tetap saja kesulitan untuk mendapatkan sambutan yang hangat dari UE. Tulisan ini menempatkan beberapa argumen teoritis berdasarkan konsep Pos-kolonialisme yang ditujukan untuk menemukan salah satu alasan kenapa UE memberikan penolakan yang konsisten kepada Turki. Karena tulisan ini berdiri di atas sudut pandang Pos-kolonialisme, tulisan ini percaya bahwa kecenderungan Euro-sentrisme yang tertanam dalam pola pikir UE menjadi alasan kenapa penolakan tersebut selalu terjadi. Tulisan ini terdiri dari beberapa fitur. Setelah menyampaikan pengantar singkat, akan ada penjelasan sederhana untuk menggambarkan teori yang digunakan. Bagian diskusi berisi beberapa penjelasan yang bersumber dari beberapa pertanyaan; Kenapa UE memperlakukan Turki dengan beda dibandingkan Yunani? Apakah Turki mampu memenuhi persyaratan Kriteria Kopenhagen? Apakah UE benar-benar cenderung berperilaku diskriminatif perihal perizinan Turki untuk bergabung ke dalam badannya?

Kata Kunci: Uni Eropa (UE), Turki, Pos-kolonialisme, Euro-sentrisme

INTRODUCTION

\section{The groundwork for Turkey's eager- ness to get into European Union's headquarters}

Following the collapse of the Ottoman empire in 1922, Turkey's governance dimension shifted into a modern republic-style design and the image of a powerful and energetic empire' that usually referred to the so-called 'the land of four seasons' altered conversely. As a consequence of Turkey's reduction of power and influence, the European economy, particularly in terms of trade, which usually posed Turkey as a central partner, had no longer remain. As Turkey had been less needed for mutually beneficial cooperation, most European countries had found their ways and prevented Turkey's intervention, or even a tiny portion of participation, in their economic transaction (Morelli V. L., 2013). Despite having a troublesome 
tragedy, Turkey has been able to escape from the bondage of a footdragging national development, thus making it a country that has rapid advancement in social, political, and economic affairs.

Seeking economic development ambitiously, modern Turkey believes that possessing an admission ticket as a European Union (EU) member will enhance their economic strength. This perspective is entrenched within Turkey's perspective since the EU can incorporate an eyebrowraising development and prosperity towards its member states' economic realm. The stonewalling for Turkey's attempt to wave their flag in Brussels is high. Notwithstanding plenty of rejection been received, Turkey still has a considerable effort to be an EU member. Economic-based motivation is not the only driving force behind Turkey's joining as an EU member and the political reason to gain recognition and a lucrative position on the worldwide stage. Turkey perceives the EU as an extraordinary supranational organization in which the members can get a different, dominant level of competency compare with nonEU members (Modebadze \& Sayin, 2015).
The interwoven discomfort between Turkey and the EU

The cooperation between Turkey and the EU has been running since 1959. In numerous disputes, both actors' relations have been interrupted, yet two remain unscathed severely, making the gradual thawing of ties sometimes. The bickering between Turkey and the EU is commonly caused by economic and political-related activity. The dispute in trade and economic aspects between both actors, one among other reasons, was caused by the potency of Turkey's economic power, maintaining a considerable bargaining position in the atmosphere of economicrelated negotiation. The supporting evidence is observable in Turkey's economic intervention towards Bulgaria and Greece. Turkey tried to liberalize service to create a bargain for the EU's economic stability (Hakura, 2018). In the political landscape, Turkey often got plunge into the watershed of tension with the EU members state since the questioning of Turkey's democracy and political stability frequently echoed. Under this circumstance, Turkey received an antagonistic nickname as 'the most controversial EU member candidate'. Some may argue that the longstanding 
dispute between Turkey and EU members country such as Cyprus and Greece, although those crises had been receded into history, serve as the basis of EU member states' qualm to Turkey's political stability (European Union Center of Excellence, 2008).

The dilemma in economic and political scope becomes a challenging disagreement, making Turkey a burdensome obstacle to solving their way to become an EU member. On the other side, Turkey is also dealing with a sort of EUproposed regulation that should be fulfilled entirely. However, considering these disputes and obstacles, Turkey should keep accepting all of the policy and the result from the EU decision. Although demanding, Turkey has no other path other than obeying the EU's requirements as it serves as the supreme decision-maker that determines Turkey's status in the EU.

\section{Turkey dilemma as the candidate status in the EU}

Turkey got problematic approval from the $\mathrm{EU}$ due to some regulations, making a longwinded dealing occurred along the negotiation process. Turkey was endorsed as an EU member as the candidate status in 1987. The opportunity seems to be a sweet promise in Turkey's view, believing that they will be a member shortly. As several requirements are still in the absence status and Turkey needs to match their political and economic condition with the Copenhagen criteria from the EU, Turkey should explore a long and tedious 'road' to arrive in Brussels. In one flashpoint, Greece's acceptance as one of the EU members has become one of Turkey's questions. Turkey may point out that the EU's openness only intended to particular states, making the EU has painted a gloomy picture of favoritism. Compared to Greece's economic and political condition, Turkey is better or may not even be far-fetched to suggest superior.

This paper examines EU regulations towards Turkey and subsequently seeks to address the following question 'is the EU standard or requirements fair enough toward Turkey compare with the acceptance of Greece as the full members of the EU?'. This paper believes that post-colonialism theory may answer the questions above. Therefore, the following section projects the theory in a modest elaboration. Afterward, the discussion section would posit 
its place and stems into several branches; EU unequal treatment against Turkey; The political criteria based on Copenhagen criteria; the economic criteria based on the Copenhagen Treaty; EU discrimination regulation toward Turkey Euro-centrism.

\section{Theoretical Framework: Post-colo- nialism}

The literature on postcolonialism discusses a wide array of issues in politics. The postcolonialist way of thinking entered the international relations theory realm more critically (Brown, 1994). Scholars of international relations have deeply blended in the discussion of post-colonialbased criticism and have spawned many essential publications, albeit discreetly without realizing themselves as post-colonial theorists (Wilkens, 2017). L. H. M. Ling has incorporated an essential contribution in introducing postcolonialism of international relations as a more applicable and inclusive approach and alternative to existing works of literature on international relations and global order. Not only she has transcended the degree of a profound postcolonialism critique towards the historical character that ignored the colonial roots of the European states, but also she re-enforces the Eurocentric conceptions (Ling, 2002, in Wilkens, 2017). Postcolonialism has been stamped as a concrete and mature international relations theory, which has an influential position in international relations discussion. Moreover, the position has got more expansive, particularly for post-colonial and non-Eurocentric academics when the nowadays problems burgeoning post-colonial states increase in world politics (Wilkens, 2017).

Post-colonialism emerges from literature and cultural studies and develops to be anthropology and history subject of the applicable study in analyzing international relation dynamics. Post-colonialism was derived from two words: 'post' and 'colonialism'. As a universal theory, the term 'post' is not similar to the meaning of particularly pointing about the time. However, the "post" in this context, according to Homi Bhaba, is a fighting term invoked in polemics against colonialism (Rao, 2012). On the other side, colonialism here refers to the universalism and meta-narratives which using the historical term, thus making it an ideological concept (Chibber, 2016: 1). To this end, the meaning of postcolonialism is a condition whereby 
to prevent colonial modernity in the present, which is influenced by the ongoing experience.

Post-colonialism theory tries to criticize the contemporary Western discourses related to the critical aspect in international relations, such as ideological in term of the government system, security, trade, and global capitalism, which have been constructed and represented the significant structure of international politics (Chowdhry and Nair, 2002: 43). One of the concepts that postcolonialism theory criticizes is Euro-centrism. This concept believes that comprehending modernity begins and ends within Europe. Consequently, this concept supports the thesis arguing that the standardization of modernity is coming from Europe and that continent has a high degree of legitimations in deciding influential regulation. It is reflected in how the western created a discourse that became a temporary standard in the world's crucial aspects, such as politics and economic (Michael Freeden, Lyman Tower Sargent and Marc Stears, 2012).

In this paper, this theory and its concepts will be used as a tool to explain the reason behind why has Turkey not been accepted as the EU members, unlike Greece, which could be readily accepted as a member of the EU even though both of those countries have the same problems in terms of the economic and political aspect. It is also expected to describe Eurocentrism's effect on the EU decision and regulation toward Turkey that could be categorized as a discriminating regulation. Using the Copenhagen criteria, other countries such as Cyprus and Greece could enter the EU without any specific hindrance, albeit they have a parallel economic and political atmosphere with Turkey.

\section{DISCUSSION}

\section{Unequal treatment by EU against Turkey compared to Greece}

Historically, Turkey wanted a member started in 1963 when the EU was a community concerned with economic integration (Tocci, 2014). Turkey's dream became much more extensive continuously in 1987. Unfortunately, Turkey was rejected because of its crucial economic instability, human rights violations, and other specific political issues. Subsequently, in 1999, Turkey was successfully involved as the EU member's candidate. To this day, Turkey's status in the EU remains unchanged. 
Greece is also one of the countries that have a desire to become an EU member. Fortunately, Greece could readily be accepted as a member of the EU, unlike Turkey. Greece applied to join the European Community in 1975 and successfully accepted since 1981 (Rankin, 2015). Despite the economic and political instability condition, Greece became one of the EU members for a long time. Greece was also dealing with the political crisis, democracy instability, having a dispute with Turkey, and ever led by a dictatorship leader (Lyrintzis, 2011). Political instability distributes large swathes of effect towards Greece's economic inflation enmeshed in the economic crisis (OECD, 2018). Nonetheless, Greece was permitted to pass the requirement, although they dealt with Turkey's exact problem. This phenomenon serves as one question regarding how exactly EU regulation works to decide new members.

Copenhagen criteria is one of the treaties constituting the criteria that new or the EU member's candidate should fulfill. The political and economic fields are the most eye-catching aspects that should be considered for all EU applicants (European Commission, 2016). This paper would like to explain the application of Copenhagen criteria to analyze Euro-centrism in EU authority, particularly EU decision towards Turkey.

\section{The Political Criteria Based on Copenhagen Criteria}

Besides economic, politics is the core of Copenhagen criteria that all candidates and EU members should pay serious attention to achieve the standard fulfillment. Politicalbased standards of Copenhagen criteria includes human right issue; the assurance of minority individuals or groups' rights and a stable democracy based on EU standardization. Those standards are the most critical requirements that become Turkey's obstacle to becoming the EU members. Turkey had a considerable effort to match its political condition with the criteria attached by the EU since 2004. Some may argue that Turkey has successfully achieved the Copenhagen criteria in a political aspect. Yet, until today, the EU still does not recognize it (Hochleitner, 2005).

Greece was also dealing with many political and economic instability explained above. However, the EU did not consider it. Arguably, Copenhagen-based political criteria were adopted by Greece in 1999. Greece has become 
an EU member in 1981, and the criteria have not been implemented yet (European Union, 2019). From this fact, not only did the EU signify a one-sided adherence to its law, but also it implied the favoritism and Euro-centrism tendency manifested by intentional discrimination against Turkey.

According to the Copenhagen criteria, Turkey has inevitably made a significant endeavor to solve its political problems, especially to achieve comprehensive democracy implementation. One of Turkey's efforts to create good democracy was by using a democratic system to choose the seat of leadership. Turkey has used democracy system since 1946 with two political party systems. Turkey was facing a couple of coup d'état by the military intervention, which could not last long (Al-Jazeera Press, 2016 ). Unfortunately, the EU utilized that historical background to became its guise of rejecting Turkey as an EU member. The EU could not disagree that Turkey's current condition is much better in terms of democracy adherence.

Turkey also had to convince its domestic policy to fit the Copenhagen treaty's standard of human rights. The other issue that becomes the EU reason was related to many human rights violations that the Ankara administration did (Cakmak, 2003). Those criteria should be fulfilled if Turkey wants to join as an EU member, even though those criteria are complicated to achieve.

Compared to Turkey's political situation, Greece had a relatively robust political aspect while being the EU candidate. At that time, some EU member countries' presidents considered Greece and Turkey's dispute, the political crisis that affects the economic inflation, and human rights. Nonetheless, eventually, Greece could still pass the obstacle and become the EU members. This unfairness proves that the EU is blind and biased to perceive Greece's political instability.

\section{The Economic Criteria based on Copenhagen Treaty}

The second criteria that become most important and have to be considered are related to the economic aspect. EU gives a complicated requirement in terms of the state's economic capability. Those requirements are related to the state's macroeconomic stability, inflation and ability to provide citizens economic-related necessities (European Commission , 2018). However, Turkey was 
struggling enough to create their economic condition to fit with the EU criteria resulting in Turkey's development has become one of the fastest economic growth in the world (Gormez, 2014).

Furthermore, before an economic recession approaching, Turkey was in excellent condition for its economic growth. Yet, it still did not pass the Copenhagen treaty requirement because the $\mathrm{EU}$ argued the Lira inflation was still possible and remained an unstable currency (Nelson, 2018). Even though Turkey's economic growth has increased significantly (see the graph below), the EU still has not accepted Turkey as a member.

Figure 1. Turkey's economic growth

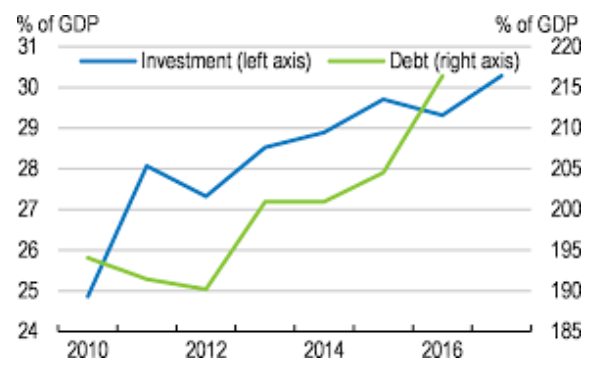

Source: OECD (2018), OECD Economic Outlook and OECD Financial Accounts (databases).

Link: https://doi.

org/10.1787/888933798504

Considering Greece's economic criteria, its economic condition was more unstable compared with Turkey. Economic inflation is still dealing with Greece until now (Kirby, 2015). Oddly, Greece can pass the regulation toward the criteria that Copenhagen criteria have been posited. If comparing the economic condition between both countries, Turkey will have the highest economic capability instead of Greece, as proven by the graph below.

Figure 2. Economic growth comparison between Turkey and Greece

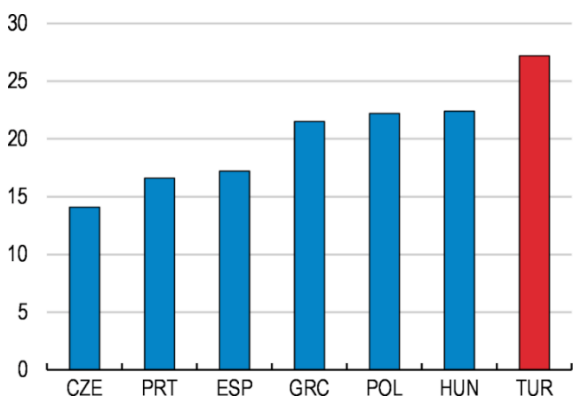

Source: Medina and Schneider, "Shadow Economies Around the World, 2018 Link: https://doi. org/10.1787/888933798542

Figure 2 above shows that Turkey's economic condition is higher than Greece's economic condition. Nonetheless, it does not become one factor that can trigger the EU to accept Turkey as a new member. Nevertheless, a flexible regulation toward the EU 
requirement can depend on the $\mathrm{EU}$ as the supreme leader. However, it can discriminate against Turkey in this case.

\section{EU discriminative regulation to- ward Turkey as the effect of Euro- centrism}

$\mathrm{EU}$ was not consistent in implementing their vision or goals towards Turkey because of their decisive authority. The EU's goal is to "fight social exclusion and discrimination" (European Union , 2019). Unfortunately, the EU is relatively essential to entirely implement this goal, especially toward Turkey, which still has no equal right to become an $\mathrm{EU}$ member. The post-colonialism perspective would argue that the EU's discriminative gesture towards Turkey reflects the Euro-centrism sense embedded within European society. Turkey admission's refusal ostensibly implies that Europe is the decision-maker and a paradigm that is highly bereft of basis in postcolonialism.

The Copenhagen criteria are the regulation labeled as a 'discriminative' mechanism. This conclusion is derived from the high criteria of political and economic aspects only to Turkey compared to the other countries' requirements before 1999, primarily before implementing it. The EU's different treatment is precise whereby Greece's presence is preferable, despite their economic and political power (Kollias, 2003).

\section{CONCLUSION}

Post-colonialism theory sees Euro-centrism as surfacing when the EU authority firmly takes the role in creating a decision that could discriminate the EU members' candidate. This statement proves how the EU treats Greece and Turkey in a contrasting manner. Even though Turkey has much developed economic stability and political aspect, the supreme authority still depends on the EU member's country leader judgment. Turkey could not sue the EU's blatant discriminative act since they have a one-sided authoritative role.

In conclusion, Euro-centrism becomes one factor determining Turkey's fate in its future attempt to join the EU whether Turkey will be accepted or remain a candidate. The EU's attitude as the supranational organization should have a consistent decision to create regulation to prevent discrimination toward the EU member's candidate. If the recommendation is disobeyed, EU goals will be inconsistent and 
show how Euro-centristic the organization is.

\section{BIBLIOGRAPHY}

Al-Jazeera Press. (2016). Timeline: A history of Turkish Coups. Doha: Al-Jazeera.

Brown, Chris. (1994). "Turtles all the way down": Anti-foundationalism, critical theory and international relations. Millennium: Journal of International Studies, Vol. 23, No. 2.

Cakmak, C. (2003). Human Rights, The European Union and Turkey. Alternatives Turkish Journal of International Relations, 64.

EDS. (2016). "The Greek Turkish Dispute over the Aegean Sea-A threat to National Security. Kyiv: Council Meeting.

European Commission . (2018).

Turkey 2018 Report. Strasbourg : European Commission .

European Commission. (2016, December 06). European Neighbourhood Policy and Enlargement. Retrieved 04 22, 2019, from European Commission: Turkey's Accession to the European Union in terms of impact on the EU's security and defense policies - potential and drawbacks

European Union . (2019, 05 17). European Union . Retrieved from Official Website of the European Union: https:// europa.eu/european-union/ about-eu/eu-in-brief_en

European Union . (2019, 02 06). European Union. Retrieved from europe.eu: https://europa. eu/european-union/about-eu/ countries/member-countries/ greece_en

European Union Center of Excellence . (2008). Turkey's Quest for EU Membership. European Union Center of North Carolina, 2.

Firat Bilgel and Burhan Can Karahasan . (2016 ). Thirty Years of Conflict and Economic Growth in Turkey: A Synthetic Control Approach. The London School of Economics and Political Science, 13.

Geeta Chowdhry and Sheila Nair. (2002). Power, Postcolonialism and International Relations. New York: Routledge.

Gormez, Y. (2014). The Economic and Financial Stability in Turkey: A Historical Perspective. SEEMHN, 3-6. 
Hakura, F. (2018). EU-Turkey Customs Union Prospect for Modernization and Lessons for Brexit. Chatham House The Royal Institute of International Affairs, 2.

Hochleitner, E. (2005). The Political Criteria of Copenhagen and their Application to Turkey. Austrian Institute for European Security Policy, 1-4.

Howard, D. A. (2001). The History of Turkey. California: Greenwood Publishing.

Istituto Affari Internazionali (IAI). (2013). Global Turkey in Europe (Political, Economic, and Foreign Policy Dimensions of Turkey's Evolving Relationship with the EU). IAI Research Papers, 85-103.

Jacobin. (2016, 03 15). How Does the Subaltern Speak? (Chibber, Interviewer)

Kemal Dervis, Michael Emerson, Daniel Gros and Sinan Ulgen. (2004). The European Transformation of Modern Turkey. Brussels: Center of European Policy Studies.

Keridis, D. (1999). Political Culture and Foreign Policy: GreekTurkish Relations in the Era of European Integration and Globalization. A NATO Fellowship Final Report, 6.

Kirby, P. (2015). Greece Debt Crisis: Has Grexit been Avoided? London: BBC News.

Kollias, C. (2003). Greece and Turkey in the 21st Century: Conflict or Cooperation. New York: Nova Science Publisher.

Lyrintzis, C. (2011). Greek Politics in the Era of Economic Crisis: Reassessing Causses and Effect. The Hellenic Observatory or the LSE, 21.

Masters, B. (2013). The Arabs of the Ottoman Empire, 15161919 A social and Cultural History. Newyork: Cambridge University Press.

Michael Freeden, Lyman Tower Sargent and Marc Stears. (2012). The Oxford Handbook of Political Ideologies. Oxford: Oxford University Press.

Modebadze \& Sayin. (2015). Why Turkey Should Join The European Union: Arguments in Favor of Turkish Membership. Journal of Liberty and International Affairs, Vol. 1, No. 2, 6.

Morelli, V. L. (2013). European Union Enlargement: A Status Report on Turkey's Accession Negotiations. Congressional Research Service, 2. 
Morelli, V. L. (2013). European Union Enlargement: A Status Report on Turkey's Accession Negotiations. Congressional Research Service, 2.

Nashrullah, N. (2019, may 24). Republika. Retrieved from Republika.co.id: https://www. republika.co.id/berita/koran/ islam-digest-koran/16/02/14/ o 2 jc 911 - jatuh - bangun kekuasaan-islam-di-eropa

National Geographic society. (1999). National Geographic Atlas of the World. Washington DC: National Geographic, 7th Edtion.

Nelson, R. M. (2018). Turkey's Currency Crisis. Congressional Research Service, 1-2.

OECD. (2018). OECD Economic Surveys Greece. Paris: OECD.

Pinto, M. d. (2010). Turkey's Accession to the European Union in terms of impact on the EU's security and defense policies - potential and drawbacks. Revista Brasileira de Politica Internacional , 1-3.

Pinto, M. d. (2010). Turkey's Accession to the European Union in terms of impact on the EU's security and defense policies - potential and drawbacks. Revista Brasileira de Politica Internacional , 1.

Rankin, J. (2015). Greece in Europe: a short history. Wales: The Guardian.

Rao, R. (2012). Postcolonialism. Oxford University Press, 1.

Somel, S. A. (2010). The A to $Z$ of the Ottoman Empire. Maryland: Scarecrow Press.

Stanford J. Shaw \& Ezel Kural Shaw. (1977). History of the Ottoman Empire and Modern Turkey. Cambridge: Cambridge University Press; 1 st edition.

Tocci, N. (2014 ). Turkey and The European Union a Journey in the Unknown. Center on the United States and Europe at Brookings, 2.

Velikonja, M. (2005). Eurosis: A Critique of the New Eurocentrism. Ljubljana: Peace Institute.

Wilkens, Jan. (2017). Postcolonialism in International Relations. International Studies Association and Oxford University Press. 